\title{
Evidence of genetic differentiation and karyotype evolution of the sedges Cyperus ligularis L. and C. odoratus L. (Cyperaceae)
}

\section{Geyner Alves dos Santos Cruz ${ }^{1,2 *}$, Santelmo Vasconcelos ${ }^{3}$, Diego Sotero de Barros Pinangé $e^{1,3}$, Rodrigo Cesar Gonçalves-Oliveira ${ }^{1}$, Marccus Vinícius Alves ${ }^{4}$, Rodrigo Augusto Torres ${ }^{5}$ and Ana Maria Benko-Iseppon ${ }^{1}$}

Received: September 13, 2017

Accepted: December 18, 2017

\begin{abstract}
The taxonomy of Cyperaceae is complex, with genera like Cyperus harboring species complexes. We analyzed the genetic similarity between Cyperus ligularis L. and C. odoratus L. based on DNA fingerprinting and cytogenetics. Significative genetic differentiation $\left(G_{S T}=0.363\right)$ and low gene flow $\left(N_{m}=0.877\right)$ indicated a clear genetic distinction between the two species. Moreover, the clustering analysis showed two distinct genetic groups, suggesting a lack of evidence for hybridization. The phenogram revealed two different lineages, and although all individuals of $C$. odoratus were collected from plots close to each other, they possessed greater genetic diversity than that observed among individuals of $C$. ligularis, which were sampled over a wider geographic range. Variation in chromosome number within the two species exhibited the opposite pattern, indicating greater karyotype stability in $C$. odoratus with $2 n=72$ and $2 n=76$, while the diploid number for $C$. ligularis varied from $2 n=66$ to 88 . The lower genetic variation in $C$. ligularis may be a result of the founder effect associated with seed dispersion and clonal reproduction. Field observations and analysis of reproductive biology should enrich the understanding of the genetic structure of the investigated populations and their role in successional processes.
\end{abstract}

Keywords: agmatoploidy, DNA amplification fingerprinting, gene flow, genetic differentiation, hybridization

\section{Introduction}

The family Cyperaceae (sedges) presents several taxonomic uncertainties with the presence of some species complexes, most of them described for Carex spp., such as Carex flava and Carex macrocephala species complexes (Hedrén 2004; King \& Roalson 2009; Jiménez-Mejías et al. 2014), among others. For other Cyperaceae genera, there are few records of species complexes as seen in Rhynchospora (e.g., Rhynchospora glomerata) (Naczi \& Moyer 2017). Cyperus, which is among the largest genera of the family, is considered complex, with most of the controversial groups inhabiting tropical regions (Simpson et al. 2003), mainly in Brazil, with about 100 species registered in varied vegetation types (Alves et al. 2015). In the most recent phylogenetic approaches, based on morphology and molecular data (Larridon et al. 2013; Reid et al. 2014), Cyperus was not recovered as a monophyletic group, being divided in the monophyletic clade "Cyperus C4" and the paraphyletic clade "Cyperus C3". The complexity of the genus Cyperus is also perceived at the intraspecific relationships level, as seen, for instance, in the C. rigens group (Reid et al. 2014).

It has been suggested that some degree of cross-species hybridization might occur between sympatric populations of the widely distributed group of articulated spikes, which

1 Laboratório de Genética e Biotecnologia Vegetal, Departamento de Genética, Universidade Federal de Pernambuco, 50740-600, Recife, PE, Brazil 2 Instituto de Ciências Biológicas, Universidade de Pernambuco, 50100-130, Recife, PE, Brazil

3 Instituto Tecnológico Vale, 66055-090, Belém, PA, Brazil

4 Departamento de Botânica, Universidade Federal de Pernambuco, 50740-600, Recife, PE, Brazil

5 Laboratório de Genômica Evolutiva e Ambiental, Departamento de Zoologia, Universidade Federal de Pernambuco, 50740-600, Recife, PE, Brazil

* Corresponding author: geyner.alves@gmail.com 


\section{Evidence of genetic differentiation and karyotype evolution of the sedges Cyperus ligularis L. and C. odoratus L. (Cyperaceae)}

comprises highly variable species as $C$. ligularis and $C$. odoratus (Luceño \& Alves 1997). However, analyzing the internal anatomy of leaves of these two species, Martins \& Alves (2009) did not find any evidence of hybridization. Species delimitation analyses in Cyperaceae have elucidated intraspecific relationships within difficult genera by accessing DNA fingerprinting profiles and karyotype features, as in the case of species of Carex and Schoenoplectus (Hipp et al. 2007; Esselman et al. 2012; Gizaw et al. 2016). Therefore, we relied on a genetic characterization of sympatric individuals of both C. ligularis and C. odoratus, by means of DNA Amplification Fingerprinting (DAF) and cytogenetic analyses, to access their diversity and the relationship between both species.

\section{Materials and methods}

\section{Plant material}

For molecular analysis, young leaves were collected from 40 individuals of Cyperus odoratus L. and C. ligularis L. populations, 20 from each, in five collection plots in open spaces and on the border of an urban fragment of the Atlantic Forest fragment (Tab. 1), with a minimum distance of three meters among individuals (Fig. 1). For cytogenetic analyses, young root tips of both species were collected, pre-treated with $2 \mathrm{mM}$ 8-hidroxiquinolein for $4 \mathrm{~h}$ at $18^{\circ} \mathrm{C}$, and then fixed in ethanol: acetic acid (3:1) for 4-6 $\mathrm{h}$ at room temperature $\left(\mathrm{ca} .25^{\circ} \mathrm{C}\right)$.

\section{Molecular data analyses}

DNA extraction procedures followed the CTAB protocol as described by Weising et al. (2005), with minor modifications on the tissue amount ( $2 \mathrm{~g}$ to $1 \mathrm{~g}$ of fresh leaves) and the volume of the extraction buffer $(10 \mathrm{ml}$ to $12 \mathrm{ml})$. The DAF analysis was carried out following Caetano-Anollés et al. (1991) with modifications introduced by Winter et al. (2000) and Benko-Iseppon et al. (2003). The PCR reactions, with a final volume of $15 \mu \mathrm{L}$, consisted of $20 \mathrm{ng}$ of DNA template, $10 \times$ PCR buffer, $2.5 \mathrm{mM} \mathrm{MgCl}, 10 \mathrm{mM}$ dNTPmix (Fermentas), $20 \mu \mathrm{M}$ primer (Tab. S1 in supplementary material) and 1.0 U Taq polymerase (Fermentas). The DNA amplifications were performed in an Eppendorf Mastercycler Gradient thermocycler, using a program consisting of $2 \mathrm{~min}$ initial denaturation step $\left(95^{\circ} \mathrm{C}\right)$, followed by 40 cycles of $15 \mathrm{~s}$ at $95^{\circ} \mathrm{C}, 1 \mathrm{~min}$ at $35^{\circ} \mathrm{C}$ and $2 \mathrm{~min}$ at $72{ }^{\circ} \mathrm{C}$, and the reactions were completed by a final extension step of $7 \mathrm{~min}$ at $72{ }^{\circ} \mathrm{C}$. PCR products were separated by electrophoresis on $1.8 \%$ agarose gel and stained with $0.5 \mu \mathrm{g} / \mathrm{mL}$ ethidium bromide.

The selection of the most informative primers was performed from an initial set of 50 DAF primers (Tab. S1 in supplementary material) tested on four random individuals (two of each species), using as parameters the number of amplified loci and polymorphic bands. The 10 most informative primers were used to amplify the DNA of the 40 individuals of both species. The genotyping process resulted in a binary matrix of presence (1) and absence (0) of amplified DNA fragments above $100 \mathrm{pb}$.

In order to check the relationships between the two species, the genetic dissimilarity analysis was performed according to the Jaccard's coefficient (Perrier et al. 2003) using the program DARwin 6.0 (Perrier \& JacquemoudCollet 2006), to generate a phenogram based on the weighted neighbor-joining algorithm (2000 replications of bootstrap). The genetic differentiation between the two species (here represented by two populations) was accessed by $G_{S T}$, a statistical index which is appropriate to analysis where the contribution of genetic drift among populations differences is not of interest (Holsinger \& Weir 2009). Moreover, according to Wright (1931), the genetic differentiation among populations is directly related to

Table 1. Sampled of individuals of Cyperus ligularis and C. odoratus and their georeferenced locations in Recife, Pernambuco, Brazil. Abbreviation of the plot collections: Açude da Prata - AP, Estrada dos Passarinhos - EP, Ilha do Bananal - IB, Distrito de Apipucos API and Fábrica da Macaxeira - FM.

\begin{tabular}{|c|c|c|c|c|}
\hline Species & Number of individuals & Collection site & Environmental features & Geographic coordinates \\
\hline $\begin{array}{l}\text { Cyperus odoratus } \\
\quad \text { (Cур 001) }\end{array}$ & 20 & $\begin{array}{l}\text { Border of urban forest remaining } \\
\text { (Açude da Prata - AP) }\end{array}$ & $\begin{array}{l}\text { Region exposed to very humid flooding during } \\
\text { rainy season }\end{array}$ & $\begin{array}{l}8^{\circ} 00^{\prime} 24.15^{\prime \prime S} \\
34^{\circ} 56^{\prime} 57.23^{\prime \prime} \mathrm{W}\end{array}$ \\
\hline \multirow{5}{*}{$\begin{array}{l}\text { Cyperus ligularis } \\
\quad \text { (Сур 002) }\end{array}$} & 6 & Açude da Prata - AP & $\begin{array}{l}\text { Region exposed to very humid flooding during } \\
\text { rainy season }\end{array}$ & $\begin{array}{l}8^{\circ} 00^{\prime} 24.15^{\prime \prime S} \\
34^{\circ} 56^{\prime} 57.23^{\prime \prime} \mathrm{W}\end{array}$ \\
\hline & 3 & $\begin{array}{l}\text { Border of urban forest remaining } \\
\text { (Estrada dos Passarinhos - EP) }\end{array}$ & $\begin{array}{l}\text { Region perturbed by urban occupation and } \\
\text { burning activities }\end{array}$ & $\begin{array}{l}8^{\circ} 00^{\prime} 50.18^{\prime \prime S} \\
34^{\circ} 56^{\prime} 29.07^{\prime \prime} \mathrm{W}\end{array}$ \\
\hline & 2 & Open space (Ilha do Bananal - IB) & $\begin{array}{l}\text { Island surrounded by the river Capibaribe } \\
\text { characterized by grazing activities }\end{array}$ & $\begin{array}{l}8^{\circ} 01^{\prime} 30.76^{\prime \prime S} \\
34^{\circ} 56^{\prime} 08.61^{\prime \prime} \mathrm{W}\end{array}$ \\
\hline & 7 & $\begin{array}{c}\text { Open space } \\
\text { (Distrito de Apipucos - API) }\end{array}$ & Locality perturbed by urbanization & $\begin{array}{l}8^{\circ} 01^{\prime} 05.84^{\prime \prime} \mathrm{S} \\
34^{\circ} 55^{\prime} 50.88^{\prime \prime} \mathrm{W}\end{array}$ \\
\hline & 2 & $\begin{array}{l}\text { Open space } \\
\text { (Fábrica da Macaxeira - FM) }\end{array}$ & Locality perturbed by grazing activities & $\begin{array}{l}8^{\circ} 00^{\prime} 51.12^{\prime \prime S} \\
34^{\circ} 55^{\prime} 53.74^{\prime \prime} \mathrm{W}\end{array}$ \\
\hline
\end{tabular}




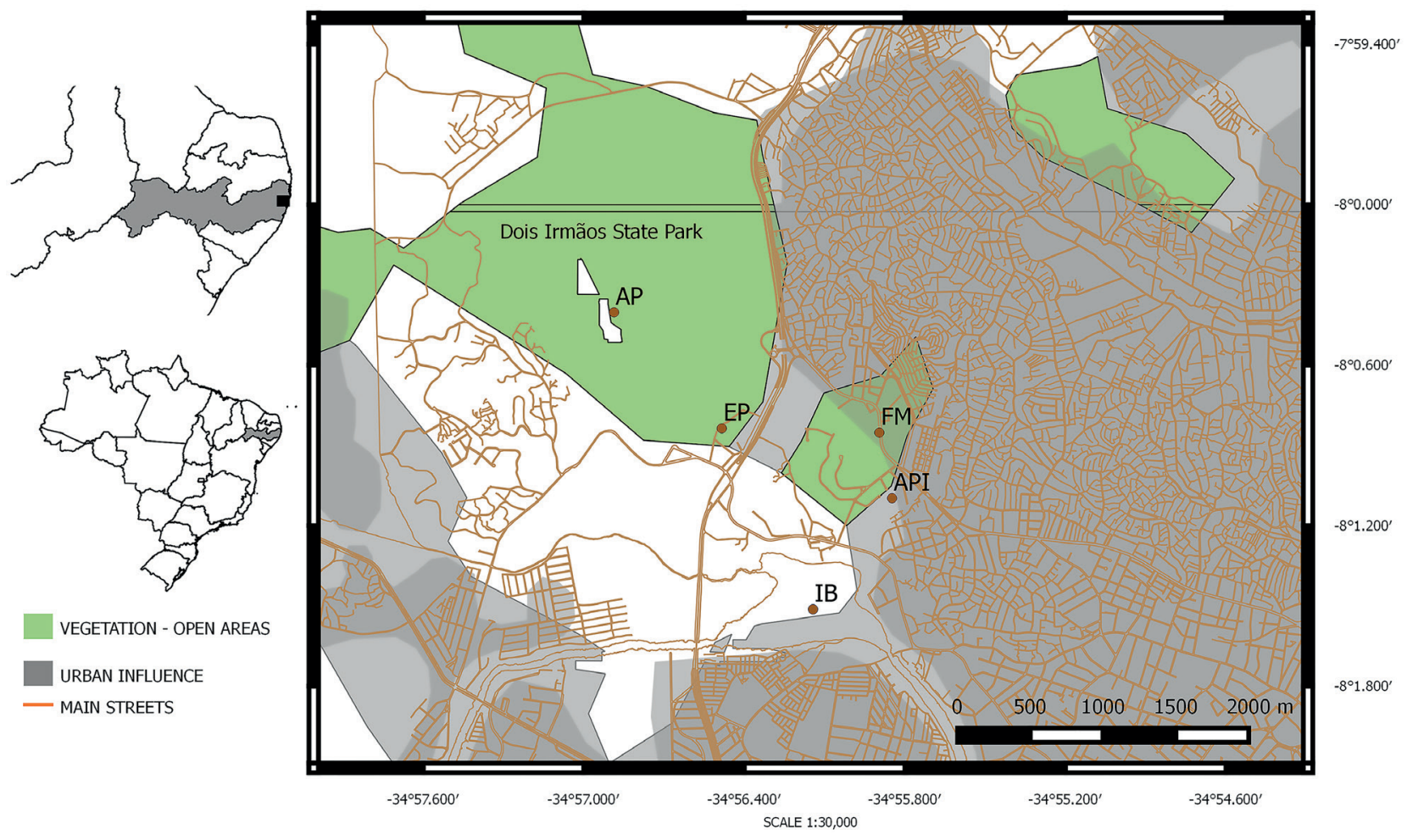

Figure 1. Plots collection of $C$. odoratus and C. ligularis located within and around the Dois Irmãos State park. Occurrence of both species - Açude da Prata - AP; Occurrence only of C. ligularis - Estrada dos Passarinhos - EP; Fábrica da Macaxeira - FM; Distrito de Apipucos - API; Ilha do Bananal - IB.

the migration, which was accessed through the number of migrants $\left(N_{m}\right)$. The $G_{S T}$ and $N_{m}$ were calculated using the Popgene 3.2 program (Yeh \& Boyle 1997) based on 1000 simulations. The genetic clusters were verified to assure whether there is evidence of interspecific hybridization between the two species. For this purpose, the software Structure 2.3.3 (Pritchard et al. 2000) was used through the Bayesian method where the K value was identified and analyzed to obtain the level of genetic admixture between the two species. The interaction between individuals was measured based on 600.000 replicates (60.000 in the burn-in stage), using the admixture model. The number of genetic clusters was inferred through the index described by Evanno et al. (2005).

\section{Cytogenetic analyses}

A total of 15 individuals of the two populations were analyzed, nine of $C$. ligularis and six of $C$. odoratus. Slides were prepared as described by Benko-Iseppon \& Morawetz (2000), with modifications. Root tips were digested in an aqueous solution of $2 \%$ cellulose (Calbiochem 21947 ) and $20 \%$ pectinase (Sigma) for $90 \mathrm{~min}$ at $37^{\circ} \mathrm{C}$. Meristems were squashed in $45 \%$ acetic acid and frozen in liquid nitrogen to remove the coverslip. Then, slides were aged for three days at room temperature, stained with CMA $(0.5 \mathrm{mg} / \mathrm{mL}, 1 \mathrm{~h})$ and DAPI ( $2 \mu \mathrm{g} / \mathrm{mL}, 30 \mathrm{~min}$ ), mounted in McIlvaine's buffer
(pH 7.0): glycerol (1:1, v/v) and stored for another three days, according to Schweizer \& Ambros (1994). After image capture of ca. 100 cells of each species (with a Leica DMLB epifluorescence microscope and an Olympus SP350 camera), slides were destained in ethanol:acetic acid (3:1, v/v) for $30 \mathrm{~min}$, followed by immersion in ethanol for $1 \mathrm{~h}$. Then, chromosome preparations were hydrolyzed in $5 \mathrm{~N} \mathrm{HCl}$ at room temperature for $20 \mathrm{~min}$ and stained with $2 \%$ Giemsa for $15 \mathrm{~min}$ and mounted with Entellan (Merck), for further image acquisition. Silver nitrate $\left(\mathrm{AgNO}_{3}\right)$ impregnation of interphase nuclei followed the protocol described by Hizume et al. (1980), with the modifications described in Vasconcelos et al. (2010). Thirty microliters of 50\% silver nitrate were added to the preparations, which were covered with a piece of nylon mesh $(24 \times 32 \mathrm{~cm})$, incubated at $37^{\circ} \mathrm{C}$ for $40 \mathrm{~min}$ in a moisture chamber, being subsequently washed in distilled water and mounted with Entellan. For the chromosome counting and the silver nitrate impregnation approaches, at least 100 and 1000 cells were analyzed per species, respectively.

\section{Results and discussion}

A total of 172 polymorphic bands were observed at intra- and interspecific levels (Tab. 2). The C. odoratus population presented the highest polymorphism level, represented by 124 polymorphic loci (Tab. 2). According 
Table 2. Number of polymorphic loci at the intra- and interspecific levels, considering the ten selected DAF primers applied in Cyperus ligularis and C. odoratus.

\begin{tabular}{|c|c|c|c|c|c|}
\hline \multirow{2}{*}{ Primer } & \multirow{2}{*}{ Sequence $\left(5^{\prime}-3^{\prime}\right)$} & \multicolumn{2}{|c|}{ Intraspecific polymorphism } & \multirow{2}{*}{ Interspecific polymorphism } & \multirow{2}{*}{ Total polymorphisn } \\
\hline & & Cyperus ligularis & Cyperus odoratus & & \\
\hline 15_1 & TGCGTGCTTGTATAA & 7 & 17 & 11 & 18 \\
\hline 15_4 & TGCGTGCTTGATATA & 8 & 13 & 16 & 16 \\
\hline 15_5 & TGCGTGCTTGAGAGA & 3 & 10 & 17 & 17 \\
\hline $15 \_6$ & TGCGTGCTTGAAGAA & 7 & 12 & 14 & 14 \\
\hline $15 \_8$ & TGCGTGCTTGTTAAT & 1 & 15 & 16 & 16 \\
\hline 15_9 & TGCGTGCTTGTTCAT & 3 & 10 & 14 & 14 \\
\hline 15_10 & AGGTCTTGGGTATAA & 6 & 12 & 14 & 14 \\
\hline 15_12 & AGGTCTTGGGTAGGC & 21 & 14 & 28 & 28 \\
\hline 15_14 & GTGGGCTGACGTGGG & 6 & 16 & 18 & 18 \\
\hline OPJ-16 & TCTCCGCCCT & 12 & 5 & 17 & 17 \\
\hline- & Total & 74 & 124 & 165 & 172 \\
\hline
\end{tabular}

to Hollingsworth \& Ennos (2004), for a reliable estimation of genetic diversity with dominant markers, at least 50 polymorphic loci are necessary for both resolving tree topologies and differentiating populations. The authors conclude that there is a direct relationship between the consistency of the genetic diversity analysis and the number of obtained polymorphic loci. Therefore, our results for the two analyzed Cyperus species are well supported, considering the relatively high number of sampled loci, despite the low number of sampled individuals.

\section{Genetic dissimilarity and clustering analyzes}

As previously mentioned, there are evidences of natural interspecific hybridization among sympatric populations of related Cyperus species (e.g., C. iria and C. microiria; Chozin \& Yasuda 1991), as suggested for C. odoratus and C. ligularis by Luceño \& Alves (1997). Therefore, considering this hypothesis, we analyzed the genetic dissimilarity between these two species.

The analysis of population genetic differentiation $\left(G_{\mathrm{ST}}\right)$ and gene flow $\left(N_{m}\right)$ between the sampled species revealed a clear differentiation between the two species, with $G_{S \mathrm{~T}}=$ 0.363 and $N_{m}=0.877$, considering that values of $G_{S \mathrm{~T}}>0.25$ (Wright 1978) and $N_{m}<1$ indicate a favorable scenario for genetic differentiation (Almeida et al. 2003). Moreover, the Bayesian clustering analysis also indicated no evidence of hybridization between the species, although some individuals of $C$. ligularis and $C$. odoratus presented subtle evidences of ancestral mixing, which also may be associated with the highly polymorphic nature of the DAF markers. Interestingly, three genetic clusters were observed, being two distinct groups between C. odoratus and C. ligularis (Fig. 2). In addition, the neighbor-joining phenogram (Fig. 3) showed two main clades clearly separating $C$. odoratus and $C$. ligularis in different clusters, confirming the ITS-based molecular phylogeny by Reid et al. (2014) and the internal anatomy analysis by Martins \& Alves (2009), respectively.

Regarding the intraspecific relationships, the individuals of $C$. odoratus presented a higher level of differentiation when compared with individuals of $C$. ligularis (Tab. 2). The clustering data also makes this clear, where $C$. odoratus presents two predominant genetic clusters (Fig. 2 - red and blue clusters) showing a higher level of genetic differentiation. Moreover, a higher level of genetic differentiation was also observed in the neighbor-joining tree (Fig. 3), once several subclades with good support were separated from each other. All specimens of $C$. odoratus were collected in the vicinity of two dykes in the Dois Irmãos natural reserve. In turn, the $C$. ligularis individuals were found in various habitats, including the same as $C$. odoratus, and in different heavily perturbed open areas located nearby (Figs. 1, 3). The variability observed for $C$. odoratus may be related to higher levels of intraspecific polymorphism due to seedling recruitment, as previously reported for C. papyrus (Triest et al. 2014). On the other hand, the lower genetic differentiation observed in C. ligularis may be related to vegetative reproduction and/or a more efficient seed dispersion, which occurs by ornithochory, mirmechory, anemochory and mainly hydrochory (Linder $\&$ Rudall 2005), thus enhancing gene flow and reducing spatial aggregation among individuals (Triest et al. 2014). Moreover, we observed on the field that $C$. odoratus presents smaller clusters with more spherical rhizomes with lower density and a low number of clones, whereas $C$. ligularis has longer and thicker rhizomes with a higher number of clonal individuals. These different rates of clonal individuals between both species are probably related to the higher genetic diversity found for $C$. odoratus.

\section{Karyotype analysis}

Both species presented an intrapopulational variation in chromosome numbers, as it has been reported for other Cyperaceae genera (see Hipp 2007; Roalson 2008; Escudero et al. 2010). For $C$. odoratus, two chromosome numbers were observed: $2 n=72$ (in $67 \%$ of the cells) and $2 n=76$ (in 33\% of the cells). On the other hand, $C$. ligularis showed a higher chromosome number variation, in which the diploid number ranged from $2 n=66$ to 88 , with $2 n=82$ as the most frequent 


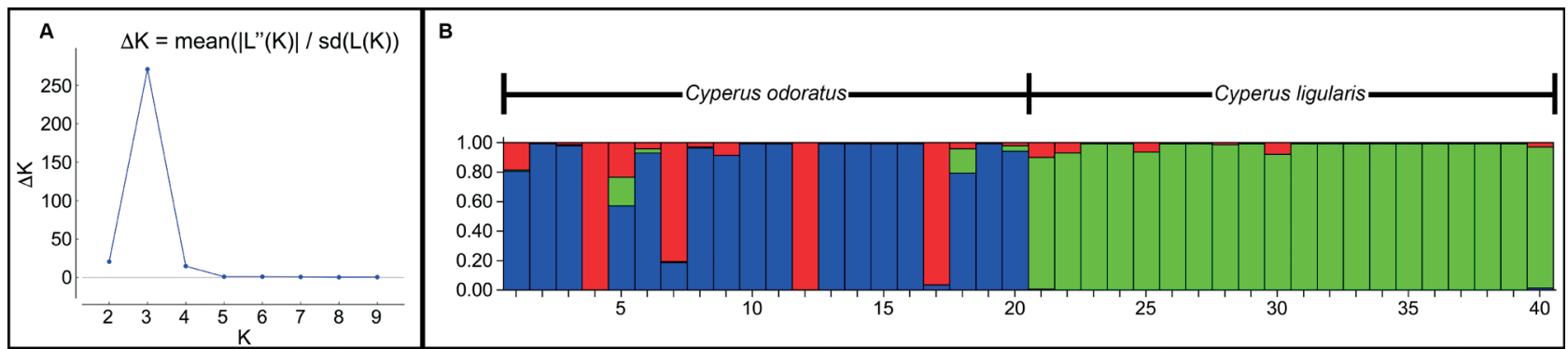

Figure 2. Bayesian clustering analysis based on Structure 2.3.3. A. Value of Delta K in accordance with the method described by Evanno et al. (2005). From the results obtained, 10 DAF primers were used, and 172 polymorphic bands were obtained for Cyperus odoratus and C. ligularis. Note that the peak occurred in $\mathrm{K}=3$. B. Ancestry of each individual in either of the two groups plotted by the software Structure version 2.3.4, using 10 DAF markers and 172 polymorphic bands for C. odoratus (individuals 1 - 20) and C. ligularis (individuals 21 - 40). Each vertical bar represents one of 40 individuals analyzed, and its genetic patrimony is noted through different colors (red, green and blue). Bar length is proportional to the ancestry values inferred in each group for each individual.

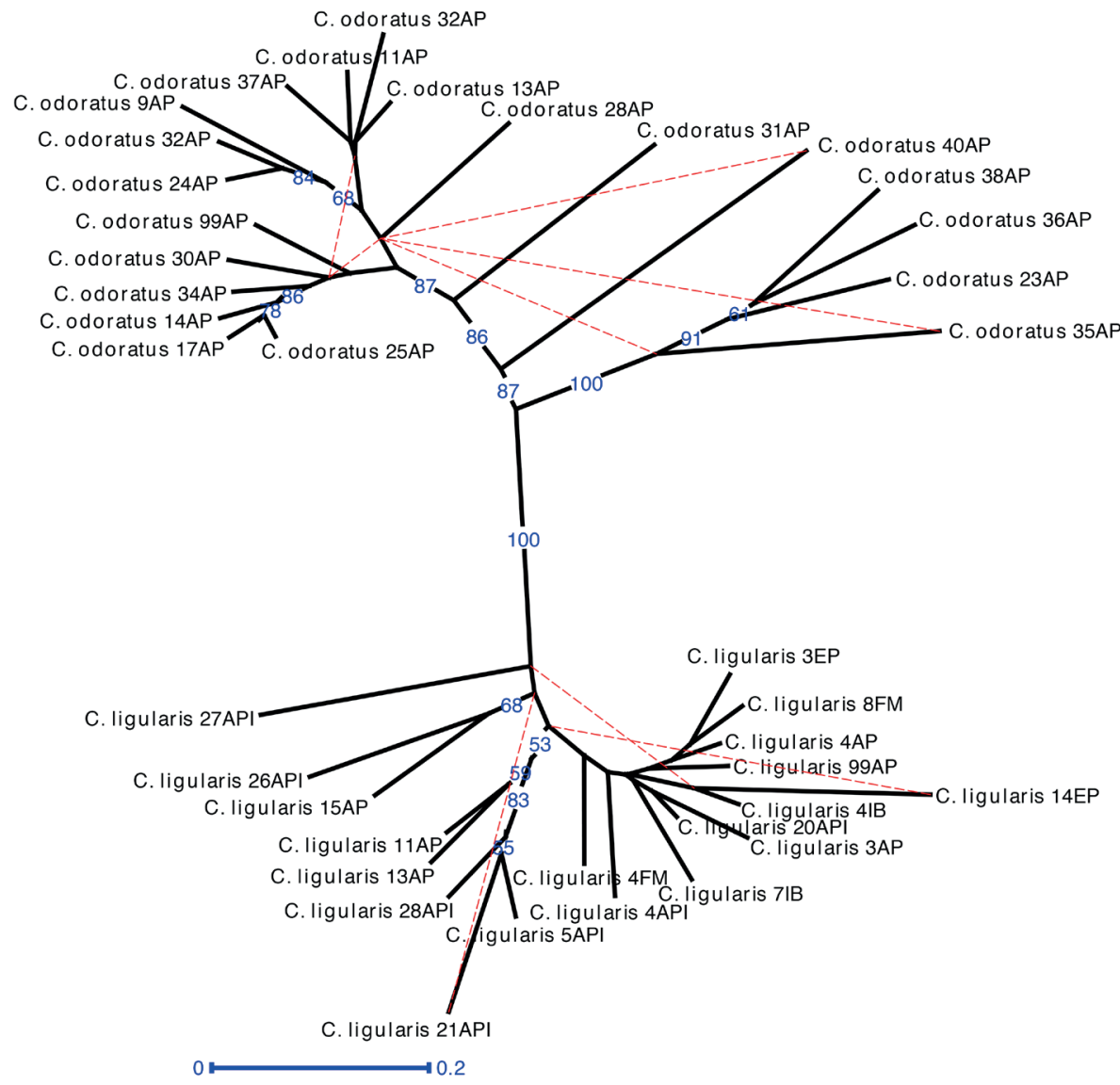

Figure 3. Neighbor-joining clustering analysis among 40 individuals of Cyperus odoratus and C. ligularis (Jaccard's coefficient and bootstrap of 2000 replicates). Collection plots: AP = Açude da Prata; API = Distrito de Apipucos; EP = Estrada dos Passarinhos; FM = Fábrica da Macaxeira; IB = Ilha do Bananal. Bootstrap values below 50 were not evidenced.

one ( $40 \%$ of the cells) (Tab. S2, Fig. S1 in supplementary material). For both species, the CMA/DAPI banding always revealed two pairs of $\mathrm{CMA}^{+}$/DAPI- signals (Fig. 4), which were associated with the two satellited chromosome pairs, also revealed by the silver nitrate impregnation (S Vasconcelos unpubl. res.).

Contrasting with the significant amount of published data on the karyological features of some genera of
Cyperaceae, such as Carex, Eleocharis and Rhynchospora (Vanzela \& Guerra 2000; Roalson 2008; Silva et al. 2010; Cabral et al. 2014), very little is known about the chromatin organization in Cyperus species. In fact, to the best of our knowledge, this is the first time that heterochromatic regions are evidenced in chromosomes of Cyperus species by means of fluorochrome banding. Consequently, it is hard to know if the coincident number of nucleolar organizer 

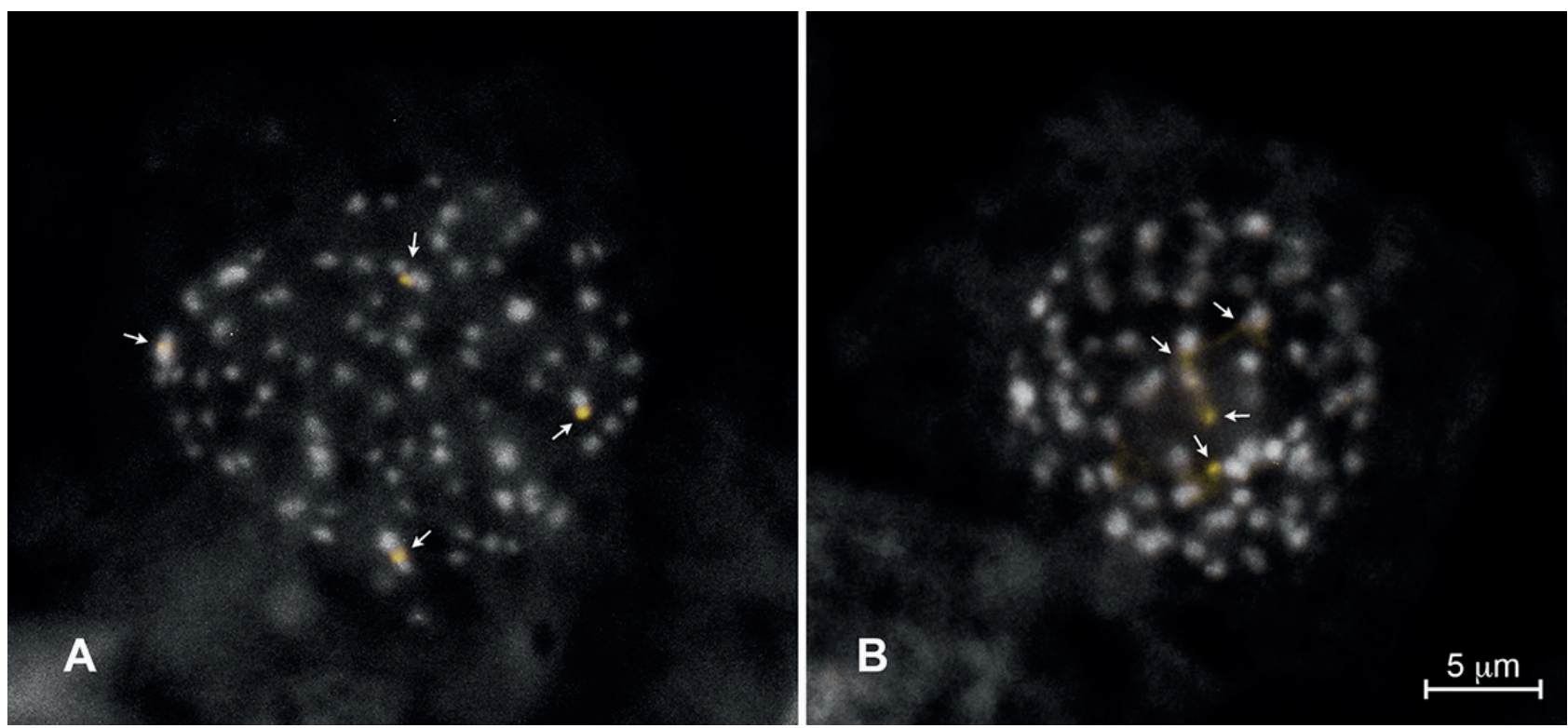

Figure 4. Mitotic metaphases of Cyperus ligularis and C. odoratus stained with CMA and DAPI. Cell of C. ligularis with $2 n=82$. A. Cell of $C$. odoratus with $2 n=72 \mathbf{B}$. Arrows indicate satellite regions with bands $\mathrm{CMA}^{+} / \mathrm{DAPI}^{-}$.

regions (NORs), which were evidenced by both CMA/DAPI and silver nitrate staining, indicates some conserved feature within the genus, as reported for other groups of Cyperaceae (Silva et al. 2010). Thus, even sharing the same number of active NORs, the different ranges of chromosome number variation among sympatric individuals of $C$. odoratus and C. ligularis reinforces the assumption of a clear separation of the two species.

The high degree of chromosome number variation in Cyperaceae members is widely attributed to the occurrence of holokinetic chromosomes in all members of the family, as well as in Juncaceae, its sister group. Thus, the presence of diffuse kinetochores may facilitate a faster karyotypic evolution by means of chromosome fission/fusion and/or translocations (Escudero et al. 2010; Chung et al. 2011). As demonstrated for Carex species and herein observed in the sampled populations, it seems that there is no correlation between geographic range, chromosome number variation and genetic diversity in these species with holokinetic chromosomes (see Escudero et al. 2010; Chung et al. 2011).

\section{Final considerations}

The natural interspecific hybridization is not rare in Cyperaceae, where species of several genera as Carex, Schoenoplectus and Isolepis present species with hybrid origin (Pedersen et al. 2016; Yano et al. 2010; 2016). Although the morphology-based suggestion of hybridization between C. odoratus and C. liguraris by Luceño \& Alves (1997), our molecular markers and cytogenetic analyses showed no evidence of hybridization.

Regarding the genetic diversity, C. odoratus surprisingly presents higher levels than C. ligularis, which is likely a result of a long period of evolution (Sheng et al. 2006) where the genetic diversity could be preserved by local vegetative regrowth of individuals. In the case of $C$. ligularis, the dispersal syndrome of the seeds, mainly by hydrochory and related with the colonization ability under various environmental conditions, seems to play a significant role in keeping the gene flow among individuals from different localities. However, the chromosome numbers showed a different picture, with $C$. odoratus less variable than $C$. ligularis, probably indicating a faster karyotypic evolution in the last species.

These results should be associated with additional field observations and specific analysis of reproductive biology, in order to enrich the knowledge concerning the dynamics and structure of the studied populations, as well as the role of these species in the successional processes and environmental restoration.

\section{Acknowledgements}

The authors thank CNPq (Conselho Nacional de Desenvolvimento Científico e Tecnológico) and CAPES (Coordenação de Aperfeiçoamento de Pessoal de Nível Superior) for financial support. We are also grateful to Dois Irmãos State Park (Recife, PE, Brazil) for permission to carry out collections and the Recife City Hall for the logistic support of the Environmental Brigade.

\section{References}

Almeida FS, Sodré LMK, Contel EPB. 2003. Population structure analysis of Pimelodus maculatus (Pisces, Siluriformes) from the Tietê and Paranapanema Rivers (Brazil). Genetics and Molecular Biology 26: 301-305. 


\section{Geyner Alves dos Santos Cruz, Santelmo Vasconcelos, Diego Sotero de Barros Pinangé, Rodrigo Cesar Gonçalves-Oliveira, Marccus Vinícius Alves, Rodrigo Augusto Torres and Ana Maria Benko-Iseppon}

Alves M, Heer SM, Trevisan R, Silva-Filho PJS, Ribeiro ARO. 2015. Cyperaceae In: Lista de Espécies da Flora do Brasil. Rio de Janeiro, Jardim Botânico do Rio de Janeiro. http://foradobrasil.jbrj.gov.br/ jabot/floradobrasil/FB100. 14 Mar. 2017.

Benko-Iseppon AM, Morawetz W. 2000. Cytological comparison of Calyceraceae and Dipsacaceae with special reference to their taxonomic relationships. Cytologia 65: 123-128.

Benko-Iseppon AM, Winter P, Hüttel B, Staginnus C, Muehlbauer FJ, Kahl G. 2003. Molecular markers closely linked to Fusarium resistance genes in chickpea show significant alignments to pathogenesis-related genes located on Arabidopsis chromosomes 1 and 5. Theoretical and Applied Genetics 107: 379-386.

Cabral G, Marques A, Schubert V, Pedrosa-Harand A, Schlögelhofer P. 2014. Chiasmatic and achiasmatic inverted meiosis of plants with holocentric chromosomes. Nature Communications 5: 50-70.

Caetano-Anollés G, Bassam BJ, Gresshoff PM. 1991. DNA amplification fingerprinting using short arbitrary oligonucleotide primers. Biotechnology 9: 553-557.

Chozin MA, Yasuda S. 1991. Possibility of natural hybridization between Cyperus iria L. and Cyperus microiria Steud. Journal of Weed Science and Technology 36: 282-289.

Chung KS, Weber JA, Hipp AL. 2011. Dynamics of chromosome number and genome size variation in a cytogenetically variable sedge (Carex scoparia var. scoparia, Cyperaceae). American Journal of Botany 98: 122-129.

Escudero M, Hipp AL, Luceño M. 2010. Karyotype stability and predictors of chromosome number variation in sedges: a study in Carex section Spirostachyae (Cyperaceae). Molecular Phylogenetics and Evolution 57: 353-363.

Esselman EJ, Enders TA, Smith M, Mckenzie PM. 2012. Examination of hybridization relationships between Schoenoplectus hallii and $S$. saximontanus (Cyperaceae) using ISSR markers. Phytoneuron 36: 1-9.

Evanno G, Regnaut S, Goudet J. 2005. Detecting the number of clusters of individuals using the software structure: a simulation study. Molecular Ecology 14: 2611-2620.

Gizaw A, Wondimu T, Mugizi TF, et al. 2016. Vicariance, dispersal, and hybridization in a naturally fragmented system: the afro-alpine endemics Carex monostachya and C. runssoroensis (Cyperaceae). Alpine Botany 126: 59-71.

Hedrén M. 2004. Species delimitation and the partitioning of genetic diversity - an example from the Carex flava complex (Cyperaceae). Biodiversity and Conservation 13: 293-316.

Hipp AL. 2007. Nonuniform processes of chromosome evolution in sedges (Carex: Cyperaceae). Evolution 61: 2175-2194.

Hipp AL, Rothrock PE, Reznicek AA, Berry PE. 2007. Chromosome number changes associated with speciation in sedges: a phylogenetic study in Carex section Ovales (Cyperaceae) using AFLP data. Aliso 23: 193-203.

Hizume M, Sato S, Tanaka A. 1980. A highly reproducible method of nucleolus organizing regions staining in plants. Stain Technology 55: 87-90.

Hollingsworth PM, Ennos RA. 2004. Neighbor joining trees, dominant markers and population genetic structure. Heredity 92: 490-498.

Holsinger KE, Weir BS. 2009. Fundamental concepts in genetics: genetics in geographically structured populations: defining, estimating and interpreting FST. Nature Reviews Genetics 10: 639-650.

Jiménez-Mejías P, Luceño M, Martín-Bravo S. 2014. Species boundaries within the Southwest Old World populations of the Carex flava Group (Cyperaceae). Systematic Botany 39: 117-131.

King MG, Roalson EH. 2009. Discordance between phylogenetics and coalescent-based divergence modelling: exploring phylogeographic patterns of speciation in the Carex macrocephala species complex. Molecular Ecology 18: 468-482.

Larridon I, Bauters K, Reynders M, et al. 2013. Towards a new classification of the giant paraphyletic genus Cyperus. Botanical Journal of the Linnean Society 172: 106-126.

Linder HP, Rudall PJ. 2005. Evolutionary history of Poales. Annual Review of Ecology, Evolution and Systmatics 36: 107-124.
Luceño M, Alves MV. 1997. Clave de los géneros de ciperáceas de Brasil y novedades taxonómicas y corologicas en la familia. Candollea 52: 185-191.

Martins S, Alves M. 2009. Anatomical features of species of Cyperaceae from northeastern Brazil. Brittonia 61: 189-200.

Naczi RFC, Moyer RD. 2017. Revision of the Rhynchospora glomerata species complex, focusing on the taxonomic status of $R$. leptocarpa (Cyperaceae). Brittonia 69: 114-126.

Pedersen ATM, Nowak MD, Brysting AK, Elven R, Bjora CS. 2016. Hybrid origins of Carex rostrata var. borealis and C. stenolepis, two problematic taxa in Carex section Vesicariae (Cyperaceae). PLoS One 11: e0165430. doi: https://doi.org/10.1371/journal.pone.0165430

Perrier X, Flori A, Bonnot F. 2003. Methods of data analysis. In: Hamon P, Seguin M, Perrier X, Glaszmann JC. (eds.) Genetic diversity of cultivated tropical plants. Montpellier, Science Publishers, Inc./ CIRAD. p. 31-63.

Perrier X, Jacquemoud-Collet JP. 2006. DARwin Software. http://darwin. cirad.fr/. 20 Aug. 2016.

Pritchard JK, Stephens M, Donnelly P. 2000. Inference of population structure using multilocus genotype data. Genetics 155: 945-959.

Reid CS, Carter R, Urbatsch LE. 2014. Phylogenetic insights into New World Cyperus (Cyperaceae) using nuclear ITS sequences. Brittonia 66: 292-305.

Roalson EH. 2008. A synopsis of chromosome number variation in the Cyperaceae. Botanical Review 74: 209-393.

Schweizer D, Ambros P. 1994. Chromosome banding. In: Gosden JR. (ed.) Methods in molecular biology, chromosome analysis protocols. Totowa, Humana Press. p. 97-112.

Sheng HM, An LZ, Chen T, et al. 2006. Analysis of the genetic diversity and relationships among and within species of Hippophae (Elaeagnaceae) based on RAPD markers. Plant Systematics and Evolution 260: 25-37.

Silva CR, Quintas CC, Vanzela AL. 2010. Distribution of 45S and 5S rDNA sites in 23 species of Eleocharis (Cyperaceae). Genetica 138: 951-957.

Simpson DA, Furness CA, Hodkinson TR, Muasya AM, Chase MW. 2003. Phylogenetic relationships in Cyperaceae subfamily Mapanioideae inferred from pollen and plastid DNA sequence data. American Journal of Botany 90: 1071-1086.

Triest L, Sierens T, Terer T. 2014. Diversity and fine-scale spatial genetic structure of Cyperus papyrus populations in Lake Naivasha (Kenya) using microsatellite markers. Hydrobiologia 737: 131-144.

Vanzela ALL, Guerra M. 2000. Heterochromatin differentiation in holocentric chromosomes of Rhynchospora (Cyperaceae). Genetics and Molecular Biology 23: 453-456.

Vasconcelos S, Souza AA, Gusmão CLS, Milani M, Benko-Iseppon AM, Brasileiro-Vidal AC. 2010. Heterochromatin and rDNA 5S and 45S sites as reliable cytogenetic markers for castor bean (Ricinus communis, Euphorbiaceae). Micron 41: 746-753.

Weising K, Nybom H, Wolff K, Kahl G. 2005. DNA Fingerprinting in plants, principles, methods, and applications. 2nd. edn. Boca Raton, CRC Press.

Winter P, Benko-Iseppon AM, Hüttel B, et al. 2000. A linkage map of the chickpea (Cicer arietinum L.) genome based on recombinant inbred lines from a $C$. arietinum $\mathrm{x} C$. reticulatum cross: localization of resistance genes for fusarium wilt races 4 and 5 . Theoretical and Applied Genetics 101: 1155-1163.

Wright S. 1931. Evolution in Mendelian populations. Genetics 16: 97-159. Wright S. 1978. Evolution and genetics of populations, the theory of gene frequencies. 2nd. edn. Chicago, University of Chicago Press.

Yano O, Ikeda H, Hoshino T. 2010. Molecular and cytological studies of an interspecific hybrid in the genus Schoenoplectus (Cyperaceae). Acta Phytotaxomica et Geobotanica 60: 141-149.

Yano O, Tanaka N, Ito Y. 2016. Molecular evidence for a natural hybrid between Isolepis crassiuscula and Isolepis lenticularis (Cyperaceae) in New Zealand. New Zealand Journal of Botany 54: 433-445.

Yeh FC, Boyle T. 1997. Population genetic analysis of co-dominant and dominant markers and quantitative traits. Belgian Journal of Botany 129: $157-163$ 